\title{
WEATHERING PERFORMANCE OF PARTICLEBOARDS MANUFACTURED FROM BLENDS OF FOREST RESIDUES WITH RED PINE (PINUS BRUTIA) WOOD
}

\author{
H. Turgut Sahin ${ }^{1}$, M. Burak Arslan'
}

\begin{abstract}
Red pine cone and barks combined with red pine wood particles in various proportions were used as the raw materials for one and three layered experimental particleboard manufacturing in laboratory conditions. The pine cones and barks have higher lignin, but lower holocellulose content compare to wood. For bark-based panels, the highest MOR (2.52 MPa) corresponded to the lowest thickness swelling (9.3\%) and marginally highest IB at $150^{\circ} \mathrm{C}$ and $8 \%$ adhesive level. The 24 hour thickness swelling (TS) values obtained in this study were lower than the required TS-EN 312 (2005) value of 14\% for all bark-based boards. However, the single-layer bark-based boards demonstrated higher mechanical properties compared to three-layer boards using similar manufacturing conditions. The boards exposed to atmospheric conditions have considerably darkened (-DL) and lower surface roughness changes. Meanwhile, for single-layer cone boards, the highest MOR (4.66 MPa) was found at $150^{\circ} \mathrm{C}$ and $8 \%$ adhesive level, whereas the highest IB (1.54 MPa) and lowest TS $(32.9 \%)$ were found at $150^{\circ} \mathrm{C}$ and $10 \%$ adhesive content. The cone-based panels had higher surface color changes (lightness and total color difference) compared to red pine wood panels. The particleboards produced using cone in the proportion of wood resulted in lower TS compared to boards made from only red pine wood.
\end{abstract}

Keywords: Pine cone, particleboard, red pine, pine bark, cellulose

\section{INTRODUCTION}

The need for lignocellulose-based composites is continuously increasing throughout the world. The increasing population and demand for wood-based products has generated greater pressure on forestlands. Similar effects on forests are evident in Turkey. Currently, approximately 10 million $\mathrm{m}^{3}$ of timber are harvested from forests to provide a proportion of the wood raw material for the Turkish forest products industry. However, millions of tons of industrial woods have been imported from foreign countries to meet the needs for wood in Turkey (Konukcu 2001).

Composite materials with uniform reinforcement distribution in their structure meet most end-use requirements. However, important criteria for composite manufacturing are weight and cost. The main concept of composites is that the bulk phase accepts the load over a large surface area, transferring it to the entire surface, which being stiffer increases the strength of the composite. Moreover, numerous matrix materials and as many particle or fiber types exist, which can be combined in countless ways to produce the specific desired properties (Rowell 1996).

\footnotetext{
${ }^{1}$ Suleyman Demirel University, Faculty of Forestry, Department of Forest Products Engineering, 32260 Isparta.Turkey

${ }^{2}$ Ministry of Environmental and Forestry, 06100 Ankara..Turkey

Corresponding author: halilsahin@sdu.edu.tr

Received: 28.12.2010 Accepted: 25.08.2011.
} 
One of the alternative solutions for meeting the forest products industry needs might be forest residues that are chemically and physically similar to woods. Millions of tons of forest residues are generated during harvest every year. In addition to woody parts, such as branches, small diameter trunks and roots, a considerable amount of coniferous cones and barks is generated but not commonly utilized. However, these low value forest residues are randomly laid on the forest layer, resulting in significant problems, such as barriers blocking the sun from reaching the forest soil, blockage for young trees, attractive environments for insects and fungus, and potential fire risks, especially during hot summer months. Moreover, these materials are typically lignocellulosic in nature, which is similar to woods with cellulose, lignin, and hemicellulose. Hence, these lignocellulosic sources should be considered for raw materials in the forest products industry (Sahin and Arslan 2008).

Cones are an important organ on coniferous species as they contain the reproductive structures. Coniferous cones are typically lignocellulosic materials. However, due to their high bulkiness and light properties, cones are usually not considered for collection and transportion for technical utilization; rather, they are collected primarily for seed production. Limited research exists on coniferous cone collection and utilization as a raw material in forest products industry. Many of the existing studies include chemical characterization and pharmaceutical purposes. Some studies on pine cones have examined alpha cellulose production (Sabharwal 1995), mechanical pulp production, (Sahin 1998), membrane for waste water with heavy metals (Sabharwal 1995), antifungal and antioxidant property determination (Celimene et al. 1999; Eberhardt and Young 1994, Eberhardt et al. 1994, Villagomez-Zulaica et al. 2005), anti-HIV effects (Eberhardt and Young 1996a), and chemical characterization (Eberhardt and Young 1996b).

Although extensive research has examined the utilization of tree bark in various purposes, not much information is available for pine cones in industrial use. Literature is also limited on the efficiency of using pine cones and bark in particleboard production. Moreover, no information exists regarding the effects of weathering on surface physical and chemical properties of particleboards produced from red pine cone and bark. Therefore, the aim of this study is to investigate the potential utilization of red pine cone and bark in particleboard production alone and/or in a proportionate mixture with red pine wood to determine surface properties against weathering. One of the important advantages for using these forest residues (i.e., bark and cones) in composite manufacturing is that they are renewable materials and their usage in the industry would be environmentally friendly.

\section{MATERIAL AND METHODS}

The first step of this study was to prepare experimental particle boards from red pine bark and cones (Pinus brutia Ten.) in order to determine the suitability of these forest residues for particleboards. The second step was to determine weathering performance of bark- and cone-based boards in outdoor conditions. The red pine bark and cones used in the study were collected from seedlings from a local forest office in Isparta, Turkey (see Figure 1).

The bark and cones were turned into particles through a hammer mill and screened. Particles remaining on the 2-3 $\mathrm{mm}$ and 1-1.5 $\mathrm{mm}$ sieves were used as the middle-layer and surface-layer, respectively, in three-layered panel production. The 2-3 $\mathrm{mm}$ particles were utilized for single-layer panel production. Particles were then dried at $105^{\circ} \mathrm{C}$ until at least $3 \%$ moisture content was obtained. Commercially available urea-formaldehyde (UF) resin was used as binder. The UF resin specification as follows; density: 1.27 $\mathrm{g} / \mathrm{cm}^{3}$; viscosite at $25^{\circ} \mathrm{C} 150-200 \mathrm{D}$ in/cPs; free $\mathrm{CH}_{2} \mathrm{O}$ content $(\max ) 0.19 \%$.

After spraying the adhesive on the particles in a drum blender, a particleboard mat was manually formed inside a wooden box. The target densities of the manufactured boards were $0.45-0.65 \mathrm{gr} / \mathrm{cm}^{3}$.A total of 23 boards were made with the dimensions of $500 \times 500 \times 10 \mathrm{~mm}$. After manufacturing, the boards were conditioned at $20^{\circ} \mathrm{C}$ and $65 \%$ relative humidity; test samples were cut from the experimental panels 
to determine the internal bond (IB), moduli of elasticity and rupture (MOE, MOR), and thickness swelling (TS) after 24 hour immersion in water in accordance with Turkish Standard: TS EN 310 (1999), TS EN 317 (1999) and TS EN 319 (1999). The natural weathering tests were conducted on control samples and heat-treated samples for six months on the south side of Sobu Heights in Isparta, Turkey.

The lignin content (Klason lignin) of samples was determined using the Tappi Test method 2006, T 222 om- 06 . Extraction with an $80 \%$ ethanol- $95 \%$ benzene $(1: 2 \mathrm{v} / \mathrm{v})$ system was used for the determination of extractive contents. The hot and cold water-soluble extractives were determined using the Tappi Test Method 1993, T 207 om-93. The $1 \% \mathrm{NaOH}$ solubility was determined using the Tappi Test Method 2002, T 212 om- 02 .

Ten $50 \mathrm{mmx} 50 \mathrm{~mm}$ surface roughness test samples were cut from weathered and unweathared panels. Ten roughness measurements of the surface of each type of boards and control samples were taken using a stylus-type profilometer, Mitutoyo Surftest SJ-301. Tracing speed, stylus tip diameter, and tip angle were $10 \mathrm{~mm} / \mathrm{min}, 4 \mathrm{~mm}$, and $90^{\circ}$, respectively. The root-mean-square $\left(\mathrm{R}_{\mathrm{q}}\right)$ average roughness of a surface was also calculated. Absolute color differences $(\Delta \mathrm{E})$ of the weathered boards were measured with a Datacolor Spectrophotometer 110P using CIE L*,a*, and b* standards (1976) (Kuehni 2004). A Duncan test was performed to compare board types for each property tested if the ANOVA was found to be significant.

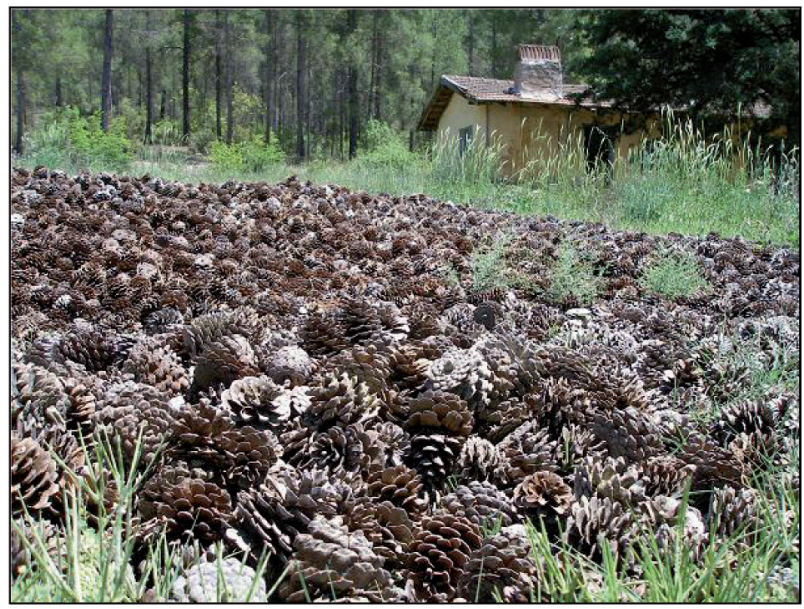

Figure 1. Red pine cones after seed production in local forest station (Isparta, Turkey)

\section{RESULT AND DISCUSSION}

Table 1 shows the chemical composition of the red pine cone, bark, and wood examined in this study. As expected, the holocellulose content of the cone was lower than that of the wood and bark. However, the cone (34.5\%) and bark (25.5\%) had higher lignin content than the red pine wood. Regarding alcohol-benzene as well as cold and hot water solubility, red pine bark was found to have much higher solubility values than cone and wood. Moreover, the $1 \% \mathrm{NaOH}$ solubility of red pine cone was $29.37 \%$, approximately two times higher than red pine wood; this reveals the high short cellulose fractions in the cone. These measurements demonstrate good agreement with the results reported for chemical constituent pine cone (Eberhardt and Young 1994, Eberhardt et al. 1994, Celimene et al. 1999). 
Table 1. Chemical composition (\%) of red pine wood, cone and bark

\begin{tabular}{|c|c|c|c|c|c|c|}
\hline Material & Holocellulose & Lignin & $\begin{array}{c}\text { Alcohol- } \\
\text { benzen } \\
(\mathbf{1 : 2}) \text { sol. }\end{array}$ & $\begin{array}{c}\text { Cold water } \\
\text { solubility }\end{array}$ & $\begin{array}{c}\text { Hot water } \\
\text { solubility }\end{array}$ & $\begin{array}{c}\text { \%1 NaOH } \\
\text { solubility }\end{array}$ \\
\hline $\begin{array}{c}\text { Red pine } \\
\text { wood }\end{array}$ & 76.2 & 23.8 & $6.43 *$ & $2.78 *$ & $3.11 *$ & $13.12 *$ \\
\hline $\begin{array}{c}\text { Red pine } \\
\text { bark }\end{array}$ & 74.5 & 25.5 & 7.5 & 6.15 & 10.76 & 4.03 \\
\hline $\begin{array}{c}\text { Red pine } \\
\text { cone }\end{array}$ & 65.5 & 34.5 & 4.1 & 2.35 & 5.5 & 29.37 \\
\hline
\end{tabular}

*data from Hafizoglu and Özalp 2007

Table 2 shows specific physical properties of single- and three-layer boards, prepared from only red pine bark particles. For single-layer boards, the highest MOR (2.52 MPa) corresponded to the lowest TS $(9.3 \%)$ and marginally highest IB found at $150^{\circ} \mathrm{C}$ and an $8 \%$ adhesive level. The results indicate that MOR can be increased by decreasing the adhesive ratio when the adhesive ratio is greater than $8 \%$ at both temperature levels. The IB increases from 0.12 at the $6 \%$ adhesive ratio to $0.18 \mathrm{MPa}$ at the $10 \%$ adhesive ratio at $125^{\circ} \mathrm{C}$ and 0.13 at the $6 \%$ adhesive ratio to $0.23 \mathrm{MPa}$ at the $10 \%$ adhesive ratio at $150^{\circ} \mathrm{C}$. The 24 hour TS values obtained in this study were lower than the required TS-EN 312 (2005) value of $14 \%$ for all boards, which probably relates to the chemical composition of the pine bark, which has a high water-resistant lignin compared to wood. Moreover, it is noteworthy that MOR and IB values obtained in this study were lower than the required TS-EN 312 (2005) values for all boards prepared from pine bark.

Due to the higher MOR and IB properties observed at $150^{\circ} \mathrm{C}$, further experiments were conducted for three-layer boards from pine bark; the properties are summarized in table 2. It was realized that increasing the adhesive ratio and temperature usually positively correlated with the IB for boards manufactured from red pine bark in single- and three-layered boards. However, the results clearly indicate that single-layer boards have higher mechanical properties compared to three-layer boards. This is somewhat surprising considering the well-organized particles in the matrix system. However, Yemele et al. (2010) reported that raw material content (i.e., black spruce or aspen bark), rather than particle size of raw materials, considerably influenced mechanical properties of bark-plastic composites. It is noteworthy that increasing adhesive content usually has positive effects on IB and MOR while improving TS. The highest MOR $(2.02 \mathrm{MPa})$ and IB $(0.23 \mathrm{MPa})$ with the lowest TS were found at $8-10 \%$ (surface/middle layer) adhesive content of boards. This suggests that the adhesive ratio had a significant effect on the MOR and IB as wood-based particleboard. Therefore, it may be possible to manufacture stronger and stiffer boards by increasing the production variables involved in this study. 
Table 2. Properties of boards prepared from red pine bark $\left(450 \mathrm{~kg} / \mathrm{m}^{3} \pm 25 \mathrm{~kg} / \mathrm{m}^{3}\right)$

\begin{tabular}{|c|c|c|c|c|}
\hline $\begin{array}{c}\text { Temperature } \\
\left({ }^{\circ} \mathrm{C}\right)\end{array}$ & $\begin{array}{c}\text { Adhesive } \\
(\%)\end{array}$ & $\begin{array}{l}\text { MOR } \\
\text { (MPa) }\end{array}$ & $\begin{array}{c}\text { IB } \\
(\mathrm{MPa})\end{array}$ & $\begin{array}{c}\text { TS (\%) } \\
(24 \mathrm{~h})\end{array}$ \\
\hline \multicolumn{5}{|c|}{ Boards from Red Pine Bark (Single-layer) } \\
\hline 125 & 6 & $\begin{array}{c}2.18 \\
\text { B } \\
(0.015) \\
\end{array}$ & $\begin{array}{c}0.12 \\
\mathrm{~A} \\
(0.002)\end{array}$ & $\begin{array}{c}11.3 \\
\text { B } \\
(0.87)\end{array}$ \\
\hline 125 & 8 & $\begin{array}{c}2.44 \\
\mathrm{D} \\
(0.009) \\
\end{array}$ & $\begin{array}{c}0.15 \\
\text { B } \\
(0,009)\end{array}$ & $\begin{array}{c}10.3 \\
\mathrm{~A} \\
(0.19)\end{array}$ \\
\hline 125 & 10 & $\begin{array}{c}2.30 \\
\mathrm{C} \\
(0.014) \\
\end{array}$ & $\begin{array}{c}0.18 \\
\mathrm{C} \\
(0.002)\end{array}$ & $\begin{array}{c}9.6 \\
\mathrm{AB} \\
(0.28) \\
\end{array}$ \\
\hline 150 & 6 & $\begin{array}{c}2.32 \\
\mathrm{C} \\
(0.012) \\
\end{array}$ & $\begin{array}{c}0.13 \\
\mathrm{D} \\
(0,002)\end{array}$ & $\begin{array}{c}13.8 \\
\mathrm{C} \\
(1.85)\end{array}$ \\
\hline 150 & 8 & $\begin{array}{c}2.52 \\
F \\
(0.023) \\
\end{array}$ & $\begin{array}{c}0.21 \\
\mathrm{E} \\
(0,003)\end{array}$ & $\begin{array}{c}9.3 \\
\text { A } \\
(1,13)\end{array}$ \\
\hline 150 & 10 & $\begin{array}{c}2.15 \\
\mathrm{~A} \\
(0.018)\end{array}$ & $\begin{array}{c}0.23 \\
F \\
(0.018)\end{array}$ & $\begin{array}{c}11.3 \\
\text { B } \\
(0.76)\end{array}$ \\
\hline \multicolumn{5}{|c|}{ Boards from Red Pine Bark (Three-layer) } \\
\hline $150(\mathrm{~B})$ & $6-8$ & $\begin{array}{c}1.1 \\
\mathrm{~A} \\
(0.017) \\
\end{array}$ & $\begin{array}{c}0.11 \\
\text { A } \\
(0.011)\end{array}$ & $\begin{array}{c}12.1 \\
\text { B } \\
(0.94)\end{array}$ \\
\hline $150(\mathrm{C})$ & $6-10$ & $\begin{array}{c}1.46 \\
\mathrm{~B} \\
(0.2) \\
\end{array}$ & $\begin{array}{c}0.15 \\
\mathrm{~A} \\
(0.02)\end{array}$ & $\begin{array}{c}9.9 \\
\mathrm{~A} \\
(0.63)\end{array}$ \\
\hline $150(\mathrm{D})$ & $8-10$ & $\begin{array}{c}2.02 \\
\mathrm{C} \\
(0.005)\end{array}$ & $\begin{array}{c}0.23 \\
\text { B } \\
(0.03)\end{array}$ & $\begin{array}{c}8.8 \\
\mathrm{AB} \\
(0.48)\end{array}$ \\
\hline TS EN & & 13 & 0.40 & 14 \\
\hline
\end{tabular}

*The numbers in pharantheses are Standard deviation

Figure 2 shows the surface color properties of red pine wood (A) and three-layered bark boards (in Table 2; B,C,D), exposed to atmospheric conditions for 6 months. The total color change (DE) varied from 12.58 to 18.33 in the experimental boards after the weathering process. However, all boards exposed to atmospheric conditions darkened considerably (-DL). The highest lightness changes of -13.29 (darkening) were observed with the B bark panel, followed by panels D, A, and C, respectively. A number of researchers have shown that the natural color of lignocellulosic substrates is modified upon weathering conditions due to the reactions of cell wall wood polymers (Fengel and Wegener 1984). In particular, lignin has various chromophore groups that readily react with atmospheric conditions (Hon 1991). The results found for bark-based panels were clearly consistent with this information. 


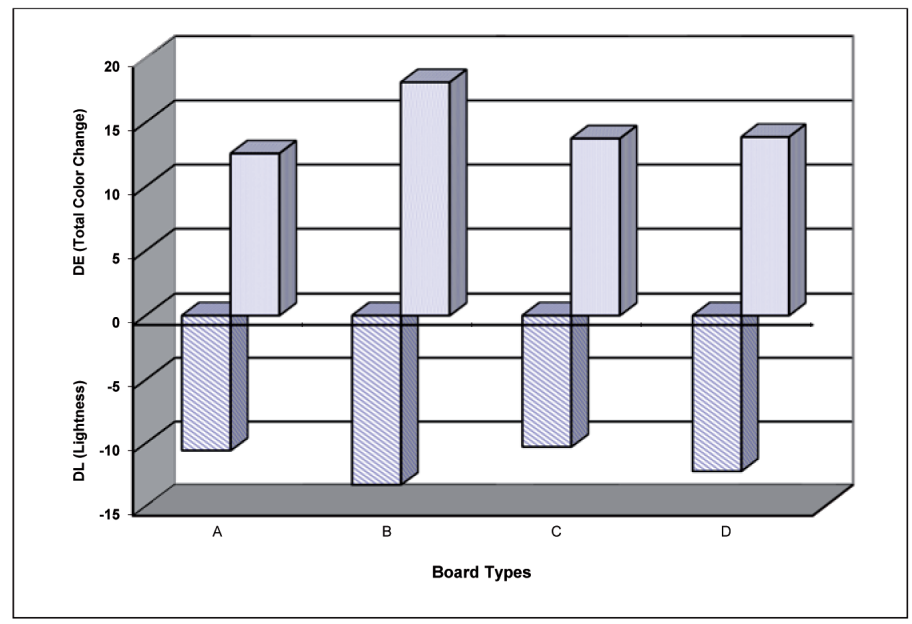

Figure 2. Color properties of red pine wood (A) and three-layered bark boards (B,C,D), exposed to athmospheric conditions for 6 months.

Figure 3 shows the surface roughness properties of experimental panels exposed to atmospheric conditions for 6 months. Initially, the pine wood-based panels had lower surface roughness values (6.42 $\mu \mathrm{m})$ than bark-based panels, which varied from 10.3 to $14.71 \mu \mathrm{m}$. For weathered panels, the surface roughness of pine panels increased from 6.42 to $22.35 \mu \mathrm{m}$ ( $248 \%$ changes). However, the bark-based weathered panels had less significant surface roughness changes. The surface roughness of panels D, $\mathrm{B}$, and $\mathrm{C}$ increased from 14.13 to $19.87 \mu \mathrm{m}$ ( $41 \%$ change), 14.71 to $23.42 \mu \mathrm{m}$ ( $60 \%$ change), and 10.3 to $25.45 \mu \mathrm{m}$ (147\% change), respectively. These results suggest that surface roughness is independent of adhesive content for bark-based panels; however, in the case of roughness change, bark panels are more stable than red pine wood panels during the weathering process. It is probably related to particle properties that particles from bark have considerably softer and flexible and thus make them better arrangements in matrix system.

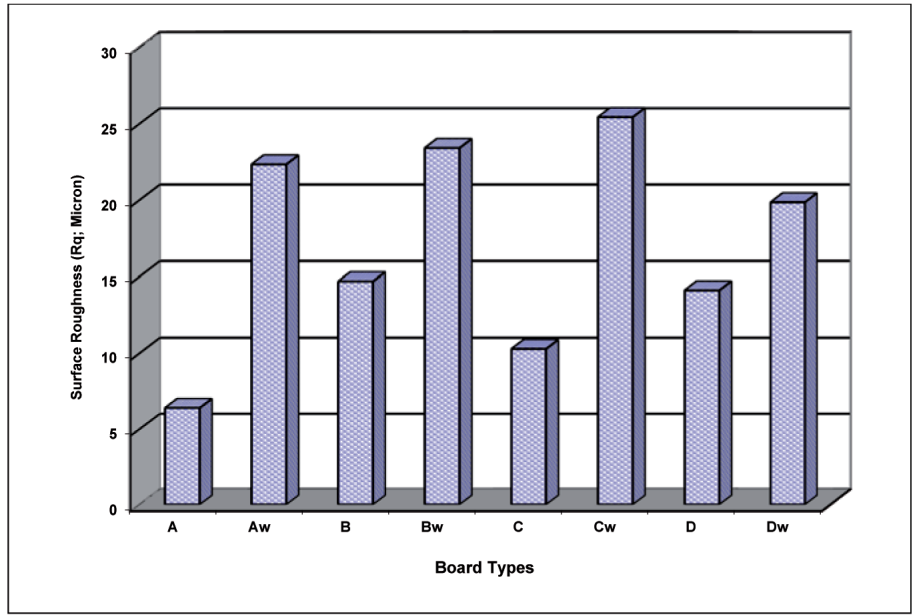

Figure 3. Surface properties of red pine wood (A) and three-layered bark boards (B,C,D), exposed to athmospheric conditions (Aw, Bw, Cw, Dw) for 6 months. 
Table 3 shows the boards prepared from only red pine cones at various experimental conditions. It appears that adhesive content considerably influenced MOR, IB, and TS values of the samples at both temperature levels. For single-layer boards, the highest MOR (4.66 MPa) was found at $150^{\circ} \mathrm{C}$ and the $8 \%$ adhesive level. However, the highest IB (1.54 MPa) and lowest TS $(32.9 \%)$ were found at $150^{\circ} \mathrm{C}$ and the $10 \%$ adhesive content. The MOR initially increased from 3.86 to 4.42 , then decreased to $3.39 \mathrm{MPa}$ when the adhesive ratio increased from 6 to 10\%. However the IB strength reached its maximum value when the adhesive ratio increased to $10 \%$ at both temperature levels. Due to higher board properties observed at $150^{\circ} \mathrm{C}$, further experiments were conducted using three-layer boards from pine cones; the results are summarized in table 3. For three-layer cone boards, the highest MOR and IB values (2.65 MPa and $0.33 \mathrm{MPa}$, respectively) were found at the $8-10 \%$ (surface/middle layer) adhesive content levels. However, these values are considerably lower than that of single-layer boards in similar conditions. The MOR, IB, and TS of panels were affected by the production variables used in this study. The TS of panels decreased as the adhesive ratio increased.

Table 3. Properties of boards prepared from Red Pine Cone

$$
\left(450 \mathrm{~kg} / \mathrm{m}^{3} \pm 25 \mathrm{~kg} / \mathrm{m}^{3}\right)
$$

\begin{tabular}{|c|c|c|c|c|}
\hline $\begin{array}{c}\text { Temperature } \\
\left({ }^{\circ} \mathrm{C}\right)\end{array}$ & $\begin{array}{c}\text { Adhesive } \\
(\%)\end{array}$ & $\begin{array}{l}\text { MOR } \\
\text { (MPa) }\end{array}$ & $\begin{array}{c}\text { IB } \\
(\mathbf{M P a})\end{array}$ & $\begin{array}{c}\text { TS (\%) } \\
\text { (24 hour) }\end{array}$ \\
\hline \multicolumn{5}{|c|}{ Borads from Red Pine Cone (One-layer) } \\
\hline 125 & 6 & $\begin{array}{c}3.86 \\
\text { B } \\
(0.022)\end{array}$ & $\begin{array}{c}0.48 \\
\mathrm{~A} \\
(0.005)\end{array}$ & $\begin{array}{c}43.9 \\
\mathrm{D}\end{array}$ \\
\hline 125 & 8 & $\begin{array}{c}4.42 \\
E \\
(0.17)\end{array}$ & $\begin{array}{c}0.66 \\
\mathrm{~B} \\
(0.003)\end{array}$ & $\begin{array}{c}46.8 \\
\mathrm{E}\end{array}$ \\
\hline 125 & 10 & $\begin{array}{c}3.39 \\
\mathrm{~A} \\
(0.063)\end{array}$ & $\begin{array}{c}0.96 \\
C \\
(0.11) \\
\end{array}$ & $\begin{array}{c}40.1 \\
\mathrm{C}\end{array}$ \\
\hline 150 & 6 & $\begin{array}{c}4.13 \\
C \\
(0.08) \\
\end{array}$ & $\begin{array}{c}0.98 \\
C \\
(0.12) \\
\end{array}$ & $\begin{array}{c}37.1 \\
\mathrm{~B}\end{array}$ \\
\hline 150 & 8 & $\begin{array}{c}4.66 \\
E \\
(0.08) \\
\end{array}$ & $\begin{array}{c}1.15 \\
\mathrm{D} \\
(0.07) \\
\end{array}$ & $\begin{array}{c}36.1 \\
\text { B }\end{array}$ \\
\hline 150 & 10 & $\begin{array}{c}4.07 \\
C \\
(0.03) \\
\end{array}$ & $\begin{array}{c}1.54 \\
\mathrm{E} \\
(0.12) \\
\end{array}$ & $\begin{array}{c}32.9 \\
\mathrm{D}\end{array}$ \\
\hline \multicolumn{5}{|c|}{ Borads from Red Pine Cone (Three-layer) } \\
\hline $150(\mathrm{E})$ & 6-8 & $\begin{array}{c}2.29 \\
\mathrm{D} \\
(0.09)\end{array}$ & $\begin{array}{c}0.22 \\
\mathrm{~B} \\
(0.002)\end{array}$ & $\begin{array}{c}27.3 \\
\text { D } \\
(0.43) \\
\end{array}$ \\
\hline $150(\mathrm{~F})$ & $6-10$ & $\begin{array}{c}2.50 \\
E \\
(0.06)\end{array}$ & $\begin{array}{c}0.29 \\
\mathrm{C} \\
(0.005)\end{array}$ & $\begin{array}{c}25.9 \\
\text { CD } \\
(1.14) \\
\end{array}$ \\
\hline $150(\mathrm{G})$ & $8-10$ & $\begin{array}{c}2.65 \\
E \\
(0.05) \\
\end{array}$ & $\begin{array}{c}0.33 \\
\mathrm{D} \\
(0.03) \\
\end{array}$ & $\begin{array}{c}23.4 \\
\mathrm{C} \\
(0.97) \\
\end{array}$ \\
\hline TS EN & & 13.0 & 0.40 & 14.0 \\
\hline
\end{tabular}

Figure 4 shows the surface color properties of three-layered cone boards exposed to atmospheric conditions for 6 months. The cone-based panels had higher surface color changes (lightness and total color difference) compared to red pine wood panel (A). The highest DE value of 13.48 and the highest DL value of -13.24 were found in panel $\mathrm{E}$, when the lowest adhesive ratio was used to produce the panel from pine cone particles. Increasing the adhesive content in the cone-based panels positively correlated with surface color stability in both DL and DE. 


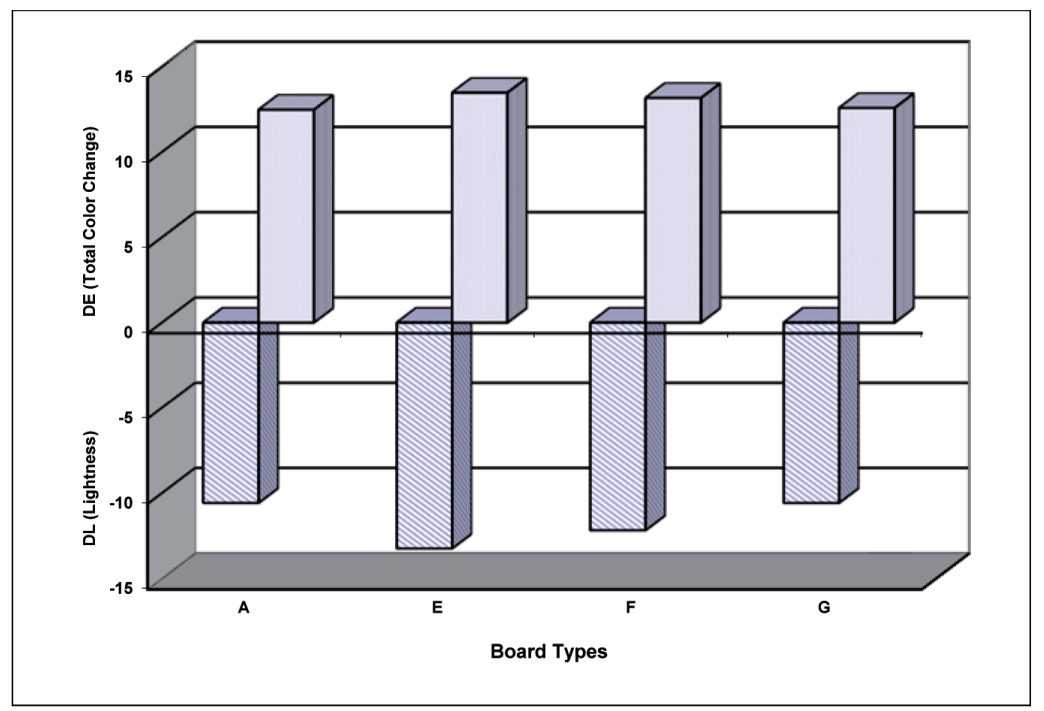

Figure 4. Surface color properties of red pine wood (A) and three-layered cone boards, $(\mathrm{E}, \mathrm{F}, \mathrm{G})$ exposed to athmospheric conditions for 6 months.

Due to the fact that higher mechanical board properties were observed with red pine cones rather than bark, using pine cones with a mixture of red pine wood at various ratios was considered to find reasonable mechanical properties for boards prepared from red pine wood proportions. Table 4 shows the properties of boards prepared from red pine cone and wood mixtures in three ratios: 1:3, 1:1, and 3:1. Cone added to wood lowered the effects of MOR and surface strength properties. However, particleboards produced using cone in equal proportions to wood lowered TS compared to boards made only from red pine wood. This result can be explained by cones higher phenolic groups, which are more hydrophobic than in wood. Ayrilmis et al. (2009) reported that the addition of $10 \%$ cone flour in MDF panels improved the panels water resistance. They also suggested that the flexibility properties and IB of panels decreased as the panels cone flour content increased. It is reasonable to suggest that cones can be useful for improving boards water resistance to a certain degree. Dos Santos et al. (2009) reported that candeia wood residue with a mixture of eucalyptus and pinus woods were viable for particleboard manufacturing. However, increased candeia wood residue percentages resulted in a reduction of MOE and MOR. In general, the results of the current study on the effect of cone ratio on red pine wood are compatible with the findings in the literature related to boards from non-wood sources. 
Table 4. Red pine wood/cone boards

(Density: $650 \mathrm{~kg} / \mathrm{m}^{3}$, Pres temp.: $150{ }^{\circ} \mathrm{C}$, Adhesive ratio: $10 \%$ )

\begin{tabular}{|c|c|c|c|c|c|c|}
\hline $\begin{array}{l}\text { Red pine cone } \\
\text { ratio } \\
\text { (C) }\end{array}$ & $\begin{array}{c}\text { Pine } \\
\text { wood ratio } \\
(\mathbf{P})\end{array}$ & $\begin{array}{l}\text { MOR } \\
\text { (MPa) }\end{array}$ & $\begin{array}{l}\text { MOE } \\
(\mathrm{MPa})\end{array}$ & $\begin{array}{c}\text { IB } \\
(\mathrm{MPa})\end{array}$ & $\begin{array}{c}\text { Surface } \\
\text { Strength } \\
\text { (MPa) }\end{array}$ & $\begin{array}{c}\text { Thickness } \\
\text { Swelling } \\
(24 \mathrm{~h})\end{array}$ \\
\hline 1 & 0 & $\begin{array}{c}8.55 \\
(0.35) \mathrm{A}\end{array}$ & $\begin{array}{c}2211 \\
(267.5) \mathrm{A}\end{array}$ & $\begin{array}{c}1.54 \\
(0.17) \mathrm{C}\end{array}$ & $\begin{array}{c}1.71 \\
(0.02) \mathrm{C}\end{array}$ & $\begin{array}{c}27.4 \\
(1.06) \mathrm{A}\end{array}$ \\
\hline 0 & 1 & $\begin{array}{c}15,5 \\
(1.18) \mathrm{D}\end{array}$ & $\begin{array}{c}9047.8 \\
(1139.5) \mathrm{D}\end{array}$ & $\begin{array}{c}1.45 \\
(0.22) \mathrm{BC}\end{array}$ & $\begin{array}{c}1.57 \\
(0.22) \mathrm{BC}\end{array}$ & $\begin{array}{c}30.3 \\
(1.01) \mathrm{B}\end{array}$ \\
\hline 1 & 3 & $\begin{array}{c}14.0 \\
(0.59) \mathrm{C}\end{array}$ & $\begin{array}{c}5558.8 \\
(315.5) \mathrm{C}\end{array}$ & $\begin{array}{c}1.21 \\
(0.06) \mathrm{AB}\end{array}$ & $\begin{array}{c}1.47 \\
(0.18) \mathrm{C}\end{array}$ & $\begin{array}{c}27.8 \\
(1.54) \mathrm{A}\end{array}$ \\
\hline 1 & 1 & $\begin{array}{c}11.6 \\
(0.5) \mathrm{B}\end{array}$ & $\begin{array}{c}3931.3 \\
(407.1) \mathrm{B}\end{array}$ & $\begin{array}{c}1.17 \\
(0.09) \mathrm{A}\end{array}$ & $\begin{array}{c}1.08 \\
(0.037) \mathrm{A}\end{array}$ & $\begin{array}{c}30.1 \\
(0.92) \mathrm{B}\end{array}$ \\
\hline 3 & 1 & $\begin{array}{c}10.9 \\
(0.53) \mathrm{B}\end{array}$ & $\begin{array}{c}2826 \\
(76.3) \mathrm{A}\end{array}$ & $\begin{array}{c}1.69 \\
(0.19) \mathrm{C}\end{array}$ & $\begin{array}{c}1.44 \\
(0.05) \mathrm{C}\end{array}$ & $\begin{array}{c}28.1 \\
(1.06) \mathrm{A}\end{array}$ \\
\hline
\end{tabular}

\section{CONCLUSION}

The results of this study demonstrated that it is feasible to produce particleboards from a mixture of red pine cone and wood particles without falling below the property value required by the standards. Red pine bark and cone are lignocellulosic materials, and the use of these renewable forest residues for manufacturing particleboards could contribute to solving raw material shortages for the particleboard industry while addressing specific environmental problems.

\section{ACKNOWLEDGEMENTS}

The authors wish to thank the financial support received for this research from Suleyman Demirel University Bilimsel Arastırmalar Proje birimi (BAP), Project number: 1542-YL-2007.

\section{REFERENCES}

Ayrilmis, N.; Buyuksari, U.; Avci, E.; Koc, E. 2009. Utilization of pine (Pinus pinea L.) cone in manufacture of wood based composite. Forest Ecology and Management 259 (1): 65-70.

Celimene, C.C.; Micales, J.A.; Ferge, L.; Young, R.A. 1999. Efficacy of pinosylvins against White-rot and Brown-Rot fungi. Hozlforschung 53 (5): 491-497.

Dos Santos, R.C.; Mendes, L.M.; Mori, F.A.; Mendes, R.F. 2009. Particleboard produced fromresidues generated after the extraction of candeia wood oil (Eremanthus erythropappus). Scientia Forestalis 37 (84): 437446.

Eberhardt, T.; Young, R.A. 1994. Conifer Seed Cone Proanthocyanidin Polymers: Characterizationby 13C NMR Spectroscopy and Determination of Antifungal Activities. Journal of Agricultural and Food Chemistry 42 (8): 1704-1708.

Eberhardt, T.L.; Han, J.S.; Micales, J.A.; Young, R.A. 1994. Decay resistance in conifer Seed Cones: Role of Resin Acids as Inhibitors of Decomposition by White-Rot fungi. Hozlforschung 48 (4) 278-284.

Eberhardt, T.; Young, R.A. 1996a. Assessment of the Anti-HIV Activity of a pine cone isolate. Planta med 62 (1): 63-65. 
Eberhardt, T.; Young, R.A. 1996b. Characterization of Conifer Seed Cone Polysacharides and Lignin. Hozlforschung 50 (5): 401-407.

Fengel, D.; Wegener, G. 1984. Wood, Chemistry, Ultrastructure, Reactions. Walter de Gruyter Public., Berlin and New York, Germany. 613 p.

Hon, N.S.D. 1991. Photochemistry of Wood. In Wood and Cellulosic. Chemistry., D. Hon and N. Shiraishi (Eds). Markel Dekker. Inc. NY, 525-555.

Hafizoglu, H.; Ozalp, M. 2007. Investigation of changes in solubility values of some non impregnated pine species used in water cooling towers. Bartın Orman Fakültesi Dergisi 12 (9): 20-25.

Kuehni, G. R. 2004. Color: An Introduction to practice and principles. $2^{\text {nd }}$ Ed. Wiley Publ. New York, 204 p.

Konukcu, M. 2001. Forests and Turkish forestry benefits statistical facts and forestry in the constituon. Turkish State Planning Organization, DPT Publication No: 2630, 258 p. Ankara, Turkey

Rowell, R.M. 1996. Opportunities for composites from agro-based resources, In: Paper and composites from agro based resources, R.M. Rowell, R.A. Young, J.K. Rowell, (Eds), CRC Press Inc, Boca Raton, FL

Sabharwal, H.H. 1995. Utilization of forest residues. Unpublished report, University of Wisconsin-Madison, WI. USA, $5 \mathrm{p}$.

Sahin, H.T. 1998. Utilization of pine cones for mechanical pulp production. Unpublished results, University of Wisconsin-Madison, WI. USA

Sahin, H.T.; Arslan, M.B. 2008. Feasibility of tree barks for producing composite panel. In Orman Mühendisli $\square \mathrm{i}$ Odasi 45. TMMOB Orman Mühendýslerý Odasi. ISSN 1301-3572, Ankara. Turkey. 4-11.

Tappi, Technical Association of the Pulp and Paper Industry. 1993. Water solubility of wood and pulp, Tappi Test method T 207-om-93. TAPPI press, Atlanta, Georgia. USA

Tappi, Technical Association of the Pulp and Paper Industry. 2002. One percent sodium hydroxied solubility of wood and pulp, Tappi Test method T 212-om-02. TAPPI press, Atlanta, Georgia. USA.

Tappi, Technical Association of the Pulp and Paper Industry. 2006. Acid-insoluble lignin in wood and pulp, Tappi Test method T 222 om-06. TAPPI press, Atlanta, Georgia. USA

TS, Turkish Standard Institute. 1999. Wood based panels - determination of modulus elasticity in bending and of bending strength. TS-EN 310, 1999. Ankara-Turkey (in Turkish).

TS, Turkish Standard Institute. 2005. Particleboards-specifications. TS-EN 312 2005. Ankara-Turkey (in Turkish).

TS, Turkish Standard Institute. 1999. Particleboards and fibreboards-determination of swelling in thickness after immersion in water. TS-EN 317, 1999. Ankara-Turkey (in Turkish).

TS, Turkish Standard Institute. 1999. Particleboards and fibreboards-determination of tensile strength perpendicular to the plane of the board. TS-EN 319, 1999. Ankara-Turkey (in Turkish).

Villagomez-Zulaica, H.; Peterson, D.M.; Herin, L.; Young, R.A. 2005. Antioxidant activity of different components of pine species. Holzforschung 59 (2): 156-162.

Yemele, M.C.N.; Koubaa, A.;Cloutier, A.; Soulounganga, P.; Wolcott, M. 2010. Effect of bark fiber content and size on the mechanical properties of bark/HDPE Composites. Composites Part A-Applied Science and Manufacturing 41 (1): 131-137. 